\title{
Expert Consensus on the Essential Preventive Knowledge of Tuberculosis for High School Students, Kathmandu, Nepal
}

\author{
Ram Sharan Gopali*1, Bijay Maharjan ${ }^{1}$ and Mika Kigawa $^{2}$ \\ ${ }^{1}$ Japan-Nepal Health and Tuberculosis Research Association, Kathmandu, Nepal \\ ${ }^{2}$ Kanagawa University of Human Services, Japan
}

*Corresponding author: Ram Sharan Gopali, Japan-Nepal Health and Tuberculosis Research Association, Kathmandu, Nepal

\section{ARTICLE INFO}

Received: February 25, 2020

Published: 幽 March 05, 2020

Citation: Ram Sharan G, Bijay M, Mika K. Expert Consensus on the Essential Preventive Knowledge of Tuberculosis for High School Students, Kathmandu, Nepal. Biomed J Sci \& Tech Res 26(2)-2020. BJSTR. MS.ID.004332.

\section{ABSTRACT}

Background: School students play an important role in the prevention of TB at all levels of community. However, there is no consensus on essential preventive messages to be taught to the students. This study aims to develop consensus on essential information about preventive measures of TB.

Method: It is qualitative research using three-round Delphi techniques among TB experts to develop agreement on essential preventive measures to prevent TB and verify their level of agreement.

Result: The essential knowledge to prevent TB is information about causative agent, DOTS process and its importance, sign and symptoms, national strategic plans, and psychosocial counseling. Nearly $91 \%$ of the experts agree that information about causative agent of TB is most essential to be informed to the students.

Conclusion: Delphi method is an effective tool to develop consensus. The results can be used for developing the IEC materials focusing school students and the communities.

Keywords: Tuberculosis; Delphi; KJ Method; Consensus

\section{Introduction}

Tuberculosis (TB) remains a major public health problem. The incidence rate of TB is 152 per 100,000 populations in Nepal and it has not declined as expected [1]. It is fundamental to prevent new infections to shrink the burden of TB. Likewise, essential and adequate knowledge of TB, its services including stigma and discrimination helps to break the barriers for TB diagnosis and treatment services [2-4]. Community people including school students need to be aware of preventive measures at all levels of communities which could be essence to lower the burden of the disease [5].

\section{Objectives}

The general objective of the study is to develop the consensus on basic and essential information on preventive measures of TB for high school students.

\section{Methods}

It is qualitative research that uses the Delphi technique to induce the opinions of experts on knowledge to prevent TB and develop the consensus with the most essential knowledge including level of agreement. The Delphi technique consist of three-round survey among the selected TB experts and agree in the essential knowledge to prevent TB (Figure 1). 


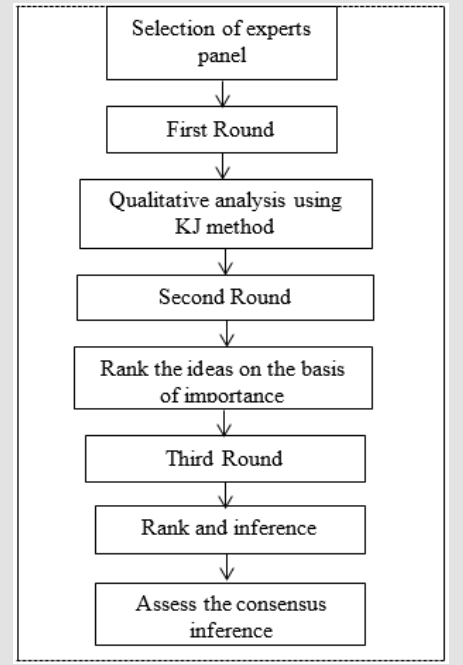

Figure 1: Steps of the research.

\section{Selection of Experts}

A heterogeneous group of twenty-two experts who have knowledge and experience in the field of a TB control program were selected for the surveys. Critical case sampling method is used because the characteristics of the case make them critical [6]. They are more likely to yield the most important information and have the greatest impact on the development of consensus on essential knowledge to prevent TB among high school students. The expert panel was selected for education and TB sector. The district TB Leprosy officer (DTLOs) of Kathmandu and Bhaktapur district and health workers of the Urban health clinic, school health teachers, and female community health volunteers (FCHVs) of the Kathmandu metropolitan city (KMC) ward 32, 10, 7 were selected purposively. Additionally, schoolteachers 2 from the public schools and 2 from the private schools located and ward 7 and 32 were selected purposively. The experts were selected based on the following characteristics that make the participants a critical case is (Table 1):

Table 1: Characteristics of the selected panel.

\begin{tabular}{|c|c|c|}
\hline Experts & Characteristics & No. of Experts \\
\hline District TB/Leprosy Officer & $\begin{array}{c}\text { They have a clear understanding of national } \\
\text { guidelines, plans, and policies related to } \\
\text { tuberculosis. They also have the problems and } \\
\text { issues in the prevention of tuberculosis at the } \\
\text { national and district level }\end{array}$ & 2 \\
\hline Health Workers & $\begin{array}{c}\text { Health workers from the DOTS clinic with } \\
\text { TB patients every day. They are familiar and } \\
\text { experienced with the problems and issues of } \\
\text { TB patients, including, their knowledge on } \\
\text { tuberculosis }\end{array}$ & 10 \\
\hline TB Volunteers & $\begin{array}{c}\text { TB volunteers are critical because they are } \\
\text { familiar and experienced with the health-seeking } \\
\text { behavior, norms, and values of the community. } \\
\text { They are also aware of the knowledge gap on } \\
\text { tuberculosis in the community. }\end{array}$ & 6 \\
\hline School Teachers & $\begin{array}{c}\text { School teachers know the educational level } \\
\text { of the students as well as the depth of the } \\
\text { knowledge they share about the prevention of } \\
\text { tuberculosis in the school. }\end{array}$ & 4 \\
\hline Total & \begin{tabular}{c}
2 \\
\hline
\end{tabular} & 22 \\
\hline
\end{tabular}

\section{Delphi Rounds}

4.2.1. First Round: After the selection of experts, each participant was given a special code number. Then, the participants were explained about the research objectives, procedures, 3 rounds of Delphi methods, including their roles and time required. Thereafter, the research assistant distributed an open-ended questionnaire to enumerate seven major preventive measures. After the distribution of the questionnaire sheet, at least 15 days were provided to the experts to write the opinions. Then, the research assistant collected the filled questionnaire. The first round of data was analyzed using the Jiro Kawakita (KJ) method. To conduct KJ method analysis, the researcher prepares black pens, many pieces of card-sized paper, chart paper [7]. Each statement was written in pieces of paper.
Then, stick in chart paper based on resemblance of meaning of the sentences. The investigator read the statements several times to identify similar and/or close opinions. Each label contains a sentence, which the researcher gets from the data. The KJ method was applied to consolidate similar or connected information to get summarized and categorized groups of items [8]. After that all the investigators reviewed the data, discussed within the team and prepared summarized 46 statements from 154 items. The summary of each group was written down on the business card-sized paper and placed on the top of each group. Lines and comments were written to explain the interrelationship among groups. After that sub-theme was prepared for the statements, based on the summaries of the sub-theme, major theme of the sentences was prepared. 
Second Round: In the second round, all the 46 items were sent to all the experts to rank from 1 to 7 based on the importance of each item for the prevention of TB. The first ranked items were given 7 score, 2 ranked was given 6 score. Similarly, the last ranked was given 1 score while for the non-ranked item, no score was given. The total points of each item were calculated. The items will be arranged in the descending order based on the importance.

Third Round: In the third round, the new ranked items based on the total score were redistributed to the experts and asked them, do they agree or disagree with the ranking. If the experts do not agree with the ranking, they were requested to provide new ranking. The numerical value will be given from 1 to 7 based on the importance of each item. The data was entered and analyzed in SPSS version 20.0. And then, the mean was calculated to indicate the group opinion while the standard deviation will calculate to indicate the level of agreement. Each statement was analyzed quantitatively by the percentage of agreement ratings, importance rankings and the number of comments made for each of the statements, and qualitatively analyzed using the thematic analysis (Figure 2).

\begin{tabular}{l}
$\begin{array}{l}\text { First Round } \\
\text { We ask the opinion about the necessary information that the } \\
\text { high school students prevent TB by open ended questionnaire }\end{array}$ \\
$\begin{array}{l}\text { Second Round } \\
\text { We consider the result of first round to make the second } \\
\text { questionnaire. We feedback the result of first round ask to } \\
\text { rank each answers based on priority }\end{array}$ \\
$\begin{array}{l}\text { Third Round } \\
\text { We repeat the same action of second round (we ask to check } \\
\text { the priority that is the result of second round) }\end{array}$ \\
\hline
\end{tabular}

Figure 2: Three round of Delphi techniques.

\section{Criteria for Consensus Level}

The Delphi technique is based on gaining consensus among the selected experts. Though there is variation in opinions and interpretation among the experts and it is quite difficult to gain $100 \%$ agreement on all the statements. In fact, no standard methods or guidelines exist for determining appropriate consensus level [9]. The consensus level is $70 \%$ of participants scored the item and no consensus: item failed to meet either of the above criteria [10-12].

\section{Ethical Consideration}

Within the Delphi, participants were allowed to participate voluntarily, and both written and informed consent was taken before the inclusion in the study. The quasi- anonymity was maintained as the participants know each other but their opinions and judgments were strictly anonymous. Along with that the confidentiality of the information, opinions, and judgments was strictly maintained. Furthermore, the ethical approval was taken from Nepal Health Research Council (NHRC), Kathmandu, Nepal (Reg.No. 530/2018).

\section{Results}

\section{Result of the Study}

Background Information of the Experts: A total of 22 experts were included in the study. Among them, 2 are DTLO, 4 school health teachers, 6 Female Community Health Volunteers, 10 health workers. The gender-wise distribution indicates, 4 are males and 18 are females. Likewise, 5 experts have up to 10 grades of education, 7 has higher secondary/diploma level, 4 has bachelor and 5 has master's degree in education. Furthermore, 5 experts have less than 10 years of experience, 5 participants have 11-15 years of experience, 3 has 16-19 years and 5 has more than 20 years of experience in tuberculosis (Table 2).

The response rate of the Experts in all the Three Rounds: In all the three rounds of the Delphi technique, all the participants were able to response which is quite good. It is possible for the 100 percent response rate due to timely and frequent follow up with the participants by the research assistant and investigators (Table 3).

The Major Theme, Sub-Theme and Statements for the Prevention of TB: A total of 154 items from 22 experts were collected. The 154 items were grouped into 46 items using the KJ methods (discussed in the methodology section). Again, these 46 items were divided into the sub-theme and then to major 7 themes such as general introduction of TB, TB screening and diagnosis, risk, treatment of TB, prevention, and control, psychosocial support, and awareness (Table 4).

Ranking of the Seven Essential Statements in the Second Round: All the 46 statements were distributed to all the experts to rank on the basis of its importance. Table 5 shows the first important statement is the general introduction of TB (agent and Types) is same across all four groups while after the first ranked statements there are variations in the statements as well as their importance across all the groups (Table 5).

Ranking of the Seven Essential Information for the Prevention of TB in the Third Round: In the third round, the experts were given the statement to re-rank the statements. Table 6 shows the ranking between FCHVs and health workers is the same, while up to the third rank it resembles schoolteachers too. However, the ranking is quite different among the DTLOs, they are focusing more on the national strategic plan and activities of NTP. It could be due to the reason that they are at district level and perceive it is important to understand national programs at the community level (Table 6). 
Table 2: Background information of the experts.

\begin{tabular}{|c|c|c|c|c|c|}
\hline \multirow{2}{*}{ Gender } & \multicolumn{4}{|c|}{ The Profession of the Experts } & \multirow{2}{*}{ Total } \\
\hline & DTLO & Health Worker & FCHV & Health Teacher & \\
\hline Male & 0 & 2 & 0 & 2 & 4 \\
\hline Female & 2 & 8 & 6 & 2 & 18 \\
\hline \multicolumn{6}{|c|}{ Age Group } \\
\hline $25-35$ & 0 & 3 & 3 & 1 & 7 \\
\hline $36-45$ & 0 & 5 & 2 & 1 & 8 \\
\hline $46-55$ & 2 & 1 & 1 & 2 & 6 \\
\hline$>56$ & 0 & 1 & 0 & 0 & 1 \\
\hline \multicolumn{6}{|c|}{ Level of Education } \\
\hline Upto 10 grade & 0 & 1 & 4 & 0 & 5 \\
\hline $\begin{array}{l}\text { Higher secondary/ } \\
\text { Diploma }\end{array}$ & 0 & 6 & 1 & 0 & 7 \\
\hline Bachelor & 2 & 2 & 0 & 2 & 6 \\
\hline Masters & 0 & 1 & 1 & 2 & 4 \\
\hline \multicolumn{6}{|c|}{ Years of Experience } \\
\hline Less than 10 & 0 & 3 & 2 & 0 & 5 \\
\hline $11-15$ & 0 & 1 & 1 & 3 & 5 \\
\hline $16-19$ & 0 & 0 & 3 & 0 & 3 \\
\hline$=>20$ years & 2 & 6 & 0 & 1 & 9 \\
\hline Total & 2 & 10 & 6 & 4 & 22 \\
\hline
\end{tabular}

Table 3: The response rate of the participants in all the three rounds.

\begin{tabular}{|c|c|c|c|}
\hline S. $\mathbf{N}$ & Round & Frequency & Response Rate (\%) \\
\hline 1 & First & 22 & 100 \\
\hline 2 & Second & 22 & 100 \\
\hline 3 & Third & 22 & 100 \\
\hline
\end{tabular}

Table 4: Major theme, sub theme and statement for the prevention of TB.

\begin{tabular}{|c|c|c|c|}
\hline S. $\mathbf{N}$ & Statements & Sub Theme & Major Theme \\
\hline 1 & General introduction (Agent \& types) of TB & 1.1 General Introduction of TB & $\begin{array}{l}\text { 1.General Introduction } \\
\text { of TB }\end{array}$ \\
\hline 2 & Present scenario of the tuberculosis & 1.1 General Introduction of TB & $\begin{array}{l}\text { 1. General Introduction } \\
\text { of TB }\end{array}$ \\
\hline 3 & Sign and Symptoms of Tuberculosis & 1.2 Sign and symptoms & $\begin{array}{l}\text { 1. General Introduction } \\
\text { of TB }\end{array}$ \\
\hline 4 & Educate about the mode of transmission and droplet infection & 1.3 Mode of transmission & $\begin{array}{l}\text { 1.General Introduction } \\
\text { of TB }\end{array}$ \\
\hline 5 & National strategic plans and activities of the National TB Programme & 1.4 Activities of NTP & $\begin{array}{l}\text { 1.General Introduction } \\
\text { of TB }\end{array}$ \\
\hline 6 & $\begin{array}{l}\text { Coordination with local bodies, community-based organizations, schools during the } \\
\text { planning and implementation of NTP }\end{array}$ & 1.4 Activities of NTP & $\begin{array}{l}\text { 1.General Introduction } \\
\text { of TB }\end{array}$ \\
\hline 7 & Effective monitoring of the National TB Programme and the TB patients & 1.4 Activities of NTP & $\begin{array}{l}\text { 1.General Introduction } \\
\text { of TB }\end{array}$ \\
\hline 8 & The criteria for the presumptive ТВ cases should clearly informed to the students & 2.1 TB diagnosis & $\begin{array}{l}\text { 2.TB screening \& } \\
\text { Diagnosis }\end{array}$ \\
\hline 9 & Methods and tools for the diagnosis for tuberculosis & 2.1 TB diagnosis & $\begin{array}{l}\text { 2.TB screening \& } \\
\text { Diagnosis }\end{array}$ \\
\hline 10 & $\begin{array}{l}\text { Location/address of the diagnostic facilities and laboratory center should be clearly } \\
\text { mentioned }\end{array}$ & 2.1 TB diagnosis & $\begin{array}{l}\text { 2.TB screening \& } \\
\text { Diagnosis }\end{array}$ \\
\hline 11 & Educate about the importance of TB screening for presumptive TB cases & 2.2 TB screening & $\begin{array}{l}\text { 2.TB screening \& } \\
\text { Diagnosis }\end{array}$ \\
\hline
\end{tabular}




\begin{tabular}{|c|c|c|c|}
\hline 12 & Inform about the TB/HIV co-infection as well as screening & 2.2 TB screening & $\begin{array}{l}\text { 2.TB screening \& } \\
\text { Diagnosis }\end{array}$ \\
\hline 13 & Educate about the TB screening for students with poor nutritional status & 2.2 TB screening & $\begin{array}{l}\text { 2.TB screening \& } \\
\text { Diagnosis }\end{array}$ \\
\hline 14 & Regular medical check up & 2.2 TB screening & $\begin{array}{l}\text { 2.TB screening \& } \\
\text { Diagnosis }\end{array}$ \\
\hline 15 & $\begin{array}{l}\text { Educate students to follow a healthy lifestyle and adopt behavior like No smoking, } \\
\text { No alcohol use, balanced diet, regular physical exercise }\end{array}$ & 3. 1 Risk behaviors of TB & 3.Risk \\
\hline 16 & Importance of a balanced diet and nutrition & 3. 1 Risk behaviors of TB & 3.Risk \\
\hline 17 & $\begin{array}{c}\text { People having a disease like diabetes, hepatitis, blood pressure, heart disease, liver } \\
\text { disease }\end{array}$ & 3.2 Risk Groups & 3.Risk \\
\hline 18 & Educate the students about safe drinking water and personal hygiene & 3.3 Environmental factors & 3. Risk \\
\hline 19 & Mitigation and prevention of air pollution & 3.3 Environmental factors & 3. Risk \\
\hline 20 & To give details of DOTS process and its importance & 4.1 Treatment of tuberculosis & 4.Treatment of TB \\
\hline 21 & TB is curable, should be treated for 6 to 8 months in DOTS & 4.1 Treatment of tuberculosis & 4. Treatment of TB \\
\hline 22 & $\begin{array}{l}\text { To educate students about address and institution, contact number of nearest DOTS } \\
\text { center }\end{array}$ & 4.1 Treatment of tuberculosis & 4. Treatment of TB \\
\hline 23 & To inform about the drugs as well as possible side effects of each drug & 4.1 Treatment of tuberculosis & 4. Treatment of TB \\
\hline 24 & TB treatment is free of cost & 4.1 Treatment of tuberculosis & 4. Treatment of TB \\
\hline 25 & TB patient should be treated with isolation & 4.1 Treatment of tuberculosis & Treatment of TB \\
\hline 26 & What is the meaning of DR and causes of MDR & 4.2MDR and XDR & 4. Treatment of TB \\
\hline 27 & Available diagnostic and treatment facilities of MDR/XDR & 4.2MDR and XDR & 4. Treatment of TB \\
\hline 28 & Always cover your mouth when you cough and sneeze & 5.1 Infection control & $\begin{array}{l}\text { 5. Prevention and } \\
\text { control }\end{array}$ \\
\hline 29 & Use of mask & 5.1 Infection control & $\begin{array}{l}\text { 5. Prevention and } \\
\text { control }\end{array}$ \\
\hline 30 & Proper management of cough/sputum & 5.1 Infection control & $\begin{array}{l}\text { 5. Prevention and } \\
\text { control }\end{array}$ \\
\hline 31 & BCG Vaccination & $\begin{array}{l}5.2 \text { Prevention and } \\
\text { management of TB }\end{array}$ & $\begin{array}{l}\text { 5. Prevention and } \\
\text { control }\end{array}$ \\
\hline 32 & Proper housing & $\begin{array}{l}5.2 \text { Prevention and } \\
\text { management of TB }\end{array}$ & $\begin{array}{l}\text { 5. Prevention and } \\
\text { control }\end{array}$ \\
\hline 33 & Educate the students about ways to prevent tuberculosis & $\begin{array}{l}5.2 \text { Prevention and } \\
\text { management of TB }\end{array}$ & $\begin{array}{l}\text { 5. Prevention and } \\
\text { control }\end{array}$ \\
\hline 34 & $\begin{array}{c}\text { Psychosocial counseling the TB patients to develop positive attitude towards TB } \\
\text { treatment }\end{array}$ & 6.1 Psychological support & 6. Psychosocial Support \\
\hline 35 & $\begin{array}{l}\text { Educate about the roles and responsibilities of family members, relatives, friends } \\
\text { towards TB patients }\end{array}$ & 6.2 Social Support & 6. Psychosocial Support \\
\hline 36 & Inform about the social, economic impact of tuberculosis among patient & 6.2 Social Support & 6. Psychosocial Support \\
\hline 37 & To organize health camps including door to door visit in the community & $\begin{array}{l}\text { 7.1 Community awareness } \\
\text { and mobilization }\end{array}$ & 7. Awareness \\
\hline 38 & Mobilize student and cured TB patients to increase awareness in the community & $\begin{array}{l}\text { 7.1 Community awareness } \\
\text { and mobilization }\end{array}$ & 7. Awareness \\
\hline 39 & $\begin{array}{l}\text { Implement community awareness activities using mass media (Television, Radio, } \\
\text { newspaper, movies) as well as group methods }\end{array}$ & $\begin{array}{l}\text { 7.1 Community awareness } \\
\text { and mobilization }\end{array}$ & 7. Awareness \\
\hline 40 & To engage private providers in community awareness activities & $\begin{array}{l}\text { 7.1 Community awareness } \\
\text { and mobilization }\end{array}$ & 7. Awareness \\
\hline 41 & To organize regular community awareness activities in the community & $\begin{array}{l}\text { 7.1 Community awareness } \\
\text { and mobilization }\end{array}$ & 7. Awareness \\
\hline 42 & $\begin{array}{l}\text { Educate the school students about tuberculosis in the local language by using the } \\
\text { audio-visual method }\end{array}$ & 7.2 Health Education & 7. Awareness \\
\hline 43 & Include the information about tuberculosis in Nepal book of the course & 7.2 Health Education & 7. Awareness \\
\hline 44 & To orient and train schoolteachers on tuberculosis & 7.2 Health Education & 7. Awareness \\
\hline 45 & Educate the school students using peer education methods & 7.2 Health Education & 7. Awareness \\
\hline 46 & Inform the school student using new technology and methods & 7.2 Health Education & 7. Awareness \\
\hline
\end{tabular}


Table 5: Group-wise ranking of the seven essential statements in the second round.

\begin{tabular}{|c|c|c|c|c|}
\hline S. $\mathbf{N}$ & Teacher & DTLO & FCHVs & HW \\
\hline 1 & $\begin{array}{c}\text { General introduction of } \\
\text { tuberculosis (Agent and types } \\
\text { of TB) }\end{array}$ & $\begin{array}{c}\text { General introduction of } \\
\text { tuberculosis (Agent and types of } \\
\text { TB) }\end{array}$ & $\begin{array}{l}\text { General introduction of } \\
\text { tuberculosis (Agent and types of } \\
\text { TB) }\end{array}$ & $\begin{array}{c}\text { General introduction of } \\
\text { tuberculosis (Agent and types } \\
\text { of TB) }\end{array}$ \\
\hline 2 & $\begin{array}{l}\text { Sign and Symptoms of } \\
\text { Tuberculosis }\end{array}$ & $\begin{array}{c}\text { National strategic plans and } \\
\text { activities of the National } \\
\text { Tuberculosis Programme }\end{array}$ & BCG Vaccination & $\begin{array}{l}\text { Psychosocial counseling the } \\
\text { TB patients to develop positive } \\
\text { attitude towards TB treatment }\end{array}$ \\
\hline 3 & $\begin{array}{l}\text { Psychosocial counseling the } \\
\text { TB patients to develop positive } \\
\text { attitude towards TB treatment }\end{array}$ & Sign and Symptoms of Tuberculosis & $\begin{array}{l}\text { A regular medical checkup by all } \\
\text { the person at least in a year }\end{array}$ & $\begin{array}{l}\text { Include the information about } \\
\text { tuberculosis in Nepal book of the } \\
\text { course }\end{array}$ \\
\hline 4 & $\begin{array}{l}\text { Educate about the mode of } \\
\text { transmission and droplet } \\
\text { infection }\end{array}$ & $\begin{array}{l}\text { To give details of DOTS process and } \\
\text { its importance }\end{array}$ & $\begin{array}{l}\text { Include the information about } \\
\text { tuberculosis in Nepal book of the } \\
\text { course }\end{array}$ & $\begin{array}{l}\text { The meaning of DR and causes } \\
\text { of MDR }\end{array}$ \\
\hline 5 & $\begin{array}{l}\text { To give details of DOTS process } \\
\text { and its importance }\end{array}$ & Present scenario of the tuberculosis & $\begin{array}{l}\text { To orient and train schoolteachers } \\
\text { on tuberculosis }\end{array}$ & $\begin{array}{l}\text { Methods and tools of TB } \\
\text { diagnosis }\end{array}$ \\
\hline 6 & BCG Vaccination & $\begin{array}{l}\text { To inform about the drugs as well } \\
\text { as possible side effects of each drug }\end{array}$ & $\begin{array}{c}\text { Educate students to follow } \\
\text { a healthy lifestyle and adopt } \\
\text { behaviour like No smoking, No } \\
\text { alcohol use, balanced diet, regular } \\
\text { physical exercise }\end{array}$ & $\begin{array}{l}\text { To give details of DOTS process } \\
\text { and its importance }\end{array}$ \\
\hline 7 & $\begin{array}{l}\text { Educate the school students } \\
\text { about tuberculosis in the local } \\
\text { language by using the audio- } \\
\text { visual method }\end{array}$ & $\begin{array}{l}\text { Information on location, contacts } \\
\text { about the diagnostic facilities and } \\
\text { laboratory centres }\end{array}$ & $\begin{array}{l}\text { To give details of DOTS process } \\
\text { and its importance }\end{array}$ & $\begin{array}{l}\text { National strategic plans and } \\
\text { activities of the National } \\
\text { Tuberculosis Programme }\end{array}$ \\
\hline
\end{tabular}

Table 6: Group-wise ranking of the seven-essential information for the prevention of TB in the third round.

\begin{tabular}{|c|c|c|c|}
\hline Teacher & DTLO & FCHV & Health Workers \\
\hline $\begin{array}{l}\text { General introduction of tuberculosis } \\
\text { (Agent and types of TB) }\end{array}$ & $\begin{array}{c}\text { National strategic plans and } \\
\text { activities of the National } \\
\text { Tuberculosis Programme }\end{array}$ & $\begin{array}{l}\text { General introduction of tuberculosis } \\
\text { (Agent and types of TB) }\end{array}$ & $\begin{array}{l}\text { General introduction of tuberculosis } \\
\text { (Agent and types of TB) }\end{array}$ \\
\hline $\begin{array}{l}\text { To give details of DOTS process and } \\
\text { its importance }\end{array}$ & $\begin{array}{l}\text { General introduction of tuberculosis } \\
\text { (Agent and types of TB) }\end{array}$ & $\begin{array}{l}\text { To give details of DOTS process and } \\
\text { its importance }\end{array}$ & $\begin{array}{l}\text { To give details of DOTS process and } \\
\text { its importance }\end{array}$ \\
\hline Sign and Symptoms of Tuberculosis & $\begin{array}{l}\text { Include the information about } \\
\text { tuberculosis in Nepal book of the } \\
\text { course }\end{array}$ & Sign and Symptoms of Tuberculosis & Sign and Symptoms of Tuberculosis \\
\hline Methods and tools of TB diagnosis & $\begin{array}{l}\text { To give details of DOTS process and } \\
\text { its importance }\end{array}$ & $\begin{array}{l}\text { Include the information about } \\
\text { tuberculosis in Nepal book of the } \\
\text { course }\end{array}$ & $\begin{array}{l}\text { Include the information about } \\
\text { tuberculosis in Nepal book of the } \\
\text { course }\end{array}$ \\
\hline $\begin{array}{l}\text { Include the information about } \\
\text { tuberculosis in Nepal book of the } \\
\text { course }\end{array}$ & $\begin{array}{c}\text { To organize regular community } \\
\text { awareness activities in the } \\
\text { community }\end{array}$ & $\begin{array}{c}\text { National strategic plans and } \\
\text { activities of the National } \\
\text { Tuberculosis Programme }\end{array}$ & $\begin{array}{c}\text { National strategic plans and } \\
\text { activities of the National } \\
\text { Tuberculosis Programme }\end{array}$ \\
\hline $\begin{array}{c}\text { National strategic plans and } \\
\text { activities of the National } \\
\text { Tuberculosis Programme }\end{array}$ & $\begin{array}{c}\text { The meaning of DR and causes of } \\
\text { MDR }\end{array}$ & Methods and tools of TB diagnosis & Methods and tools of TB diagnosis \\
\hline $\begin{array}{c}\text { Inform about the social, economic } \\
\text { impact of tuberculosis among } \\
\text { patient }\end{array}$ & $\begin{array}{l}\text { People having the disease like } \\
\text { diabetes, hepatitis, blood pressure, } \\
\text { heart disease, liver disease are } \\
\text { more risk for tuberculosis }\end{array}$ & $\begin{array}{l}\text { Psychosocial counseling the TB } \\
\text { patients to develop positive attitude } \\
\text { towards TB treatment }\end{array}$ & $\begin{array}{l}\text { Psychosocial counseling the TB } \\
\text { patients to develop positive attitude } \\
\text { towards TB treatment }\end{array}$ \\
\hline
\end{tabular}

The Difference in the Mean Score for Each Statement Between Second and Third Round: There is high variations in the mean score of each statement between the second and third round of the Delphi method. In the second round, the highest mean score is around 3.5 for the statement general introduction of $\mathrm{TB}$, as well as most of the statements, got some score. In contrast to that, the mean score of each statement has concentrated among top 7 statements and most of the statement did not receive any scoring.
However, there is minimal change in ranking of the statements. This indicates there is high level of agreement in the ranking of the statements (Figure 3).

Agreement Between Different Expert Groups: The percentage of agreement for all the 46 statements is highest among the female community health volunteers which are $89.13 \%$, it reveals that all the FCHV agree with $89 \%$ statements. Similarly, 
73.91 percent agreement among DTLOs, $71.73 \%$ of agreement among teachers and health workers (Table 7).

Percentage of the Agreement for 7 Most Important Information Among the Experts: Among all the experts, nearly $91 \%$ of the experts agree that the general introduction of TB is most essential to be communicated at the community level which is followed by message about DOTS and its importance and sign and symptoms of TB. However, the information about methods and tools of TB diagnosis is 6th essential in the ranking but has the lowest percentage of agreement between the experts, which indicates variation in the score given for the statement. Furthermore, the group theme agreement, most of the statements belong to the group one like general introduction of TB, signs, and symptoms of TB, national strategic plans and activities. However, the 7 statement does not include items from the major them risk as well as prevention and control (Table 8).

Figure 3: Difference in the mean score for each statement between the second and third round.

Table 7: Percentage of agreement between different expert groups.

\begin{tabular}{|c|c|c|}
\hline S. N & Experts & Percent of Agreement \\
\hline 1 & Teacher & 71.73 \\
\hline 2 & DTLOs & 73.91 \\
\hline 3 & Health workers & 71.73 \\
\hline 4 & FCHVs & 89.13 \\
\hline
\end{tabular}

Table 8: Percentage of the agreement for 7 most important information among the experts.

\begin{tabular}{|c|c|c|}
\hline S. N & Statements & Level of Agreement \\
\hline 1 & $\begin{array}{c}\text { General introduction of tuberculosis (Agent and } \\
\text { types) }\end{array}$ & 80.91 \\
\hline 2 & $\begin{array}{c}\text { To give details of DoTS process and its } \\
\text { importance }\end{array}$ & 86.36 \\
\hline 3 & Sign and Symptoms of Tuberculosis & 77.27 \\
\hline 4 & $\begin{array}{c}\text { Include the information about tuberculosis in } \\
\text { Nepal book of the course }\end{array}$ & 72.73 \\
\hline 5 & $\begin{array}{c}\text { National strategic plans and activities of the } \\
\text { National TB Programme }\end{array}$ & 68.18 \\
\hline 6 & Methods and tools of TB diagnosis & 72.73 \\
\hline 7 & $\begin{array}{c}\text { Psychosocial counselling the TB patients to } \\
\text { develop positive attitude towards TB treatment }\end{array}$ & 6 \\
\hline
\end{tabular}




\section{Discussion}

There is a consensus in the essential knowledge about prevention of TB to school students. The panel of the experts agrees that knowledge about general introduction about TB like agents, types is essential to be provided to the students, along with that knowledge about DOTS, signs, and symptoms of TB is important. Surprisingly, the final 7 most essential statement does not include the prevention and control of the TB. The reasons could be the experts perceive it is clinical aspects, treatment is more important than the preventive activities. On the other hand, the expert might not be much aware of the infection control measures at the community level. The level of knowledge on TB infection control was poor among almost half of the health care workers [13]. It is recommended to the NTP that, the activities should be focused on prevention and control of TB rather than clinical and treatment parts. Knowledge and perceptions about tuberculosis can stimulate, adopting TB prevention actions, service-seeking behavior and adherence to treatment of tuberculosis [14]. One of the statements that, experts agree is the inclusion of information related to tuberculosis in the Nepali book course. There is inadequate knowledge of TB and its transmission among school students which encourages the change in behaviors among them [15-17]. The reasons, maybe due to a paucity in the content of the school curriculum or the availability of information, education, and communication materials [14]. The emphasis needs to be given on increasing the knowledge, attitude, and practice of students about TB and its transmission.

Another interesting finding is that there is quite similarity between the statements of ranking between teachers and health workers, FCHV which reveals similar level of understanding about the TB between them. It also indicates it would be effective to mobilize the teachers about community activities. However, there are limited studies on the level of knowledge about TB among schoolteachers. So, it is necessary to carry out research to determine the level of knowledge among the schoolteachers. On the basis of mean rank of the statement, methods, and tools of TB diagnosis rank 6th. However, the level of agreement is lowest among the top 7 statement. The reason for it could be a high variation in the ranking of the statement between the experts. i.e some of the experts perceives it is the high importance and others as low importance. The majority of statements belong to theme 1 i.e general introduction of tuberculosis like sharing knowledge about agent, types of TB, sign, and symptoms, national strategic plans and activities. There is a variation in the mean for each statement in the second and third rounds of the Delphi technique. In the second round, the statements have lower average meanwhile in the third round of the mean has increased most some important listed statement while decreased among the lower-ranked statement in the second round which is expected. As in the third round ranked list of statements were distributed to the experts with controlled feedback based on mean rank. That has resulted in the strong consensus in the statements [18].

In the data analysis, the first round of Delphi used qualitative data analysis techniques using the KJ methods. The information was analyzed with mostly same wording with minor editing and reduced number of items after summarising and grouping of the items. While in the second and third round descriptive statistics were used. Ascertaining the level of collective opinion often entails the use of descriptive and inferential statistics [19]. One of the aims of the study is to understand the essential knowledge about prevention of TB to communicate school students and develop IEC materials on it. However, the agreed statements on the essentials knowledge on prevention of TB are limited to the aggregate representation of expert's opinions as well as there is no opportunity for participants to elaborate on their opinions and agreement. Therefore, it does not mean that all the agreed statements are most essential information for the prevention of TB. Instead, it can be used for structuring the discussion at the National level and means for raising issues for debate [19].

The participants involved in the study are from the urban areas of the country particularly the Kathmandu. So, the result of the study will be difficult to generalize. There are differences in the level of knowledge and skills among the health workers, teachers, volunteers and DTLOs from rural and urban areas. The knowledge level in TB among health workers was significantly associated with educational status, and TB training and/or orientation received [13]. Furth more, the essential information might vary on the basis of ecological areas of the country. So, it is recommended to conduct more research across different geographical areas in the country.

The response rate is for the survey is excellent despite potential chances of low response rate the survey [20]. Due to multiple feedback processes, along with long items and rounds increases the chances of low response rate in the Delphi survey [20]. A high response rate was achieved because of regular follow up with the participants and sending reminders by research assistant [21,22].

\section{Conclusion}

The essential knowledge for prevention of TB among school students should include information about the agent, types of TB, DOTS process and its importance, sign, and symptoms, national strategic plans, including the elements of psychosocial counseling to TB patients. It does not mean, that it should only include this information. The results can be used for developing the IEC materials focusing school students as well as for further research. There is need for future research with other professional groups like (Doctors, Lab personal). Consequently, the research should be implemented in the various context like urban-rural, ecological distribution. 


\section{Acknowledgement}

The research was funded by Kanagawa University of Human Services to Assistant Professor, Mika Kigawa. We would like to thank the participants, Public health section, Kathmandu Municipality and the National Tuberculosis Centre for making the study possible.

\section{References}

1. (2018) WHO Global tuberculosis report. World Health Organization.

2. Sah JP (2016) Knowledge on tuberculosis among students of higher secondary school, Lalitpur, Nepal. MOJ Public Health.

3. CP Bhatta, AB Bhatta, Bhawana Shrestha (2009) Nepalese people's knowledge about tuberculosis; SAARC. Journal of tuberculosis lung Disease and HIVAID 2: 31-37.

4. Roland Panaligan, Jude Guiang (2012) Impact of health education on the knowledge and awareness of tuberculosis among high school students. In European Respiratory Journal.

5. Scano F, Cadman H, Stop TB Initiative, World Health Organization (2019) WHO policy on TB infection control in health-care facilities, congregate settings, and households. World Health Organization, HIV Department.

6. Elmusharaf K (2018) Qualitative sampling techniques. Presentation: University of Limerick, Ireland 24.

7. Shimura K Compare and Contrast of Grounded Theory and KJ Method 12 .

8. Cheng YM (2014) An exploration into cost-influencing factors on construction projects. International Journal on Project Management 32(5): 850-860.

9. Keeney S, Hasson F, McKenna H (2006) Consulting the oracle: Ten lessons from using the Delphi technique in nursing research. Wiley Online Library 53(2): 205-212.

10. Kleynen M, Braun SM, Bleijlevens MH, Lexis MA, Rasquin SM, et al. (2014) Using a Delphi Technique to Seek Consensus Regarding Definitions, Descriptions and Classification of Terms Related to Implicit and Explicit Forms of Motor Learning. In: de Lussanet MHE (Eds.)., PLoS ONE 9(6): e100227.

\section{ISSN: 2574-1241}

DOI: $10.26717 /$ BJSTR.2020.26.004332

Ram Sharan Gopali. Biomed J Sci \& Tech Res

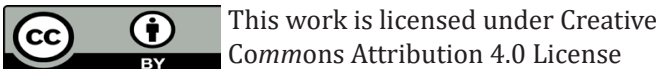

Submission Link: https://biomedres.us/submit-manuscript.php
11. Vernon W (2009) The Delphi Technique: A Review. Int J Ther Rehabil 16(2): 69-76.

12. Von der Gracht H (2012) Consensus measurement in Delphi studies: Review and implications for future quality assurance. Technological Forecasting of Social Change 79(8): 1525-1536.

13. Shrestha A, Bhattarai D, Thapa B, Basel P, Wagle RR (2017) Health care workers' knowledge, attitudes and practices on tuberculosis infection control, Nepal. BMC Infectious Disease 17(1): 724.

14. Nyasulu P, Susan Kambale, Tobias Chirwa, Teye Umanah, Isaac Singini, et al. (2016) Knowledge and perception about tuberculosis among children attending primary school in Ntcheu District, Malawi. Journal of Multidisciplinary Healthcare 9: 121-131.

15. Hibstu DT, Bago BJ (2016) Knowledge, Attitude and Practice of Tuberculosis and its Transmission among High School Students in Yirgacheffe Town, Gedeo Zone, Southern Ethiopia. Journal of Infectious Disease and Preventive Medicine 4(2): 1-6.

16. Zhao Y, Ehiri J, Li D, Luo X, Li Y (2013) A survey of TB knowledge among medical students in Southwest China: is the information reaching the target? BMJ Open 3(9): e003454.

17. Walsh K (2016) Tuberculosis awareness program: Need for longer and more rigorous follow-up. International Journal of Preventive Medicine.

18. Kobus J, Westner M (2016) Ranking-type delphi studies in IS research: Step-by-step guide and analytical extension.

19. Hasson F, Keeney S, McKenna H (2000) Research guidelines for the Delphi survey technique. Journal of Advance Nursing 32(4): 1008-1015.

20. Hsu CC, Sandford BA (2007) The Delphi Technique: Making Sense of Consensus 12(10): 8.

21. Sánchez Fernández J, Muñoz Leiva F, Montoro Ríos FJ (2012) Improving retention rate and response quality in Web-based surveys. Comput Human Behaviour 28(2): 507-514.

22. Heerwegh D, Vanhove T, Matthijs K, Loosveldt G (2005) The effect of personalizing on response rates and data quality in web surveys. International Jouranl of Social Research Methodology 8: 85-99.

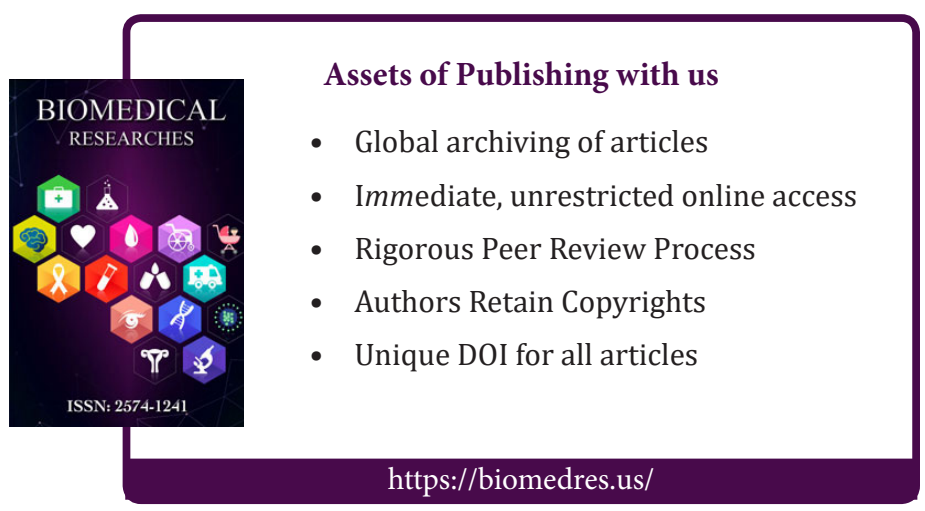

